\title{
Altruism and Sacrifice: Mafia Free Gift Giving in South Italy
}

\section{Stavroula Pipyrou, Department of Social Anthropology, University of St Andrews}

\section{Abstract}

As a social phenomenon that torments modern states, mafia receives considerable political and legal attention. The term mafia itself is often directly related to criminality and violence. Thus far violence has been employed as an analytical construct that could explain compliance with the mafia ethos. Nevertheless this schema fails to take into consideration possible discourses that make mafia tolerable. Drawing on fieldwork conducted in Reggio Calabria, South Italy, this paper explores distinctive mafia notions of giving and charity. Mafia free gifts, albeit rare, are paradoxical in the sense that through elaborate speech registers both the donor and the recipient debase the very act of gift-giving so as not to be bound in relations of reciprocity and obligation. These mafia gifts, which have so far escaped anthropological attention, are conceptualised as tropes of worldly imagining aspiring to non-worldly discourses. Status, umiltà, duty and sacrifice frame free gifting as accorded to the overt religious rhetoric of mafia hierarchy.

In this paper I argue that a) free gifting embraces a series of complex non-violent discourses which relate closely to religious duty and altruism but work alongside capitalist systems b) in principal these gifts do not bind people, yet are imbued with the potential of a relation.

\section{Key Words: Mafia; Free Gift; Altruism; Relatedness; Vincolo}




\section{Introduction}

This paper takes on the key anthropological themes of free gifting, religious duty and relatedness among the 'Ndrangheta (Calabrian Mafia) ${ }^{\mathrm{i}}$ of Reggio Calabria, South Italy. It revisits the discussion of how free gifting discourses form a constitutive part of the social (Laidlaw 2000, Simpson 2004, Sykes 2005, Venkatesan 2011). Since the critical accounts of Jonathan Parry (1986) and James Laidlaw (2000) on free gifting, more attention has been paid to this previously discarded topic (see also Raheja 1988). Some free gifts are ambivalent, fostering the potentiality to form undesired or paradoxical relations. Marcel Mauss did not leave space to examine occasions where the gift is unwanted or the relation that is fostered is itself ambivalent or redundant; "in setting up his schemata of the social phenomenon of the gift, Mauss pays little attention even to the possibility of rejection or refusal" (Young 1985:96). In some cases, as in mafia discourses, gifting does not immediately initiate a relation, but creates a dormant potentiality. As Bob Simpson argues, "creating mixed or hybrid potentialities is a delicate and conflicted business which ... entails both creating and denying connection; facilitating and preventing the flow of substance and the knowledge with which it is invested" (2011:9). This ambivalent, paradoxical, or even 'non-relation relation' (Konrad 2005) may be the outcome of giving gifts framed as free and altruistic.

Two main ideas inform the analytical endeavour of this paper. First, potentiality in relatedness with a direct reference to religious duty and second the significance of seemingly enigmatic or irrational ethnographic discourses whose rarity may render them trivial to the ethnographic gaze (Konrad 2005, Sykes 2005). In his work on reproductive technologies in Sri Lanka, Simpson has argued that donating parts or substances of the body constitutes a distinctive element of the ideology of giving and the other-worldly ends to which this giving is orientated (2004:840). Nevertheless, there is a triangular problematic which resonates between local understandings of relatedness, global ethical considerations, and religious boundaries. Transferability of bodily parts may accord with kinship ethos or go against kinship ethics and become deeply problematic, regardless of their life-giving capacity (Simpson 2004:842). 
This paradox is addressed with regards to 'Ndrangheta free gifts in Reggio Calabria where both donors and recipients seem reluctant to engage in gift-initiated social relations despite the fact that the relation is not easily shaken off, if at all. On first inspection non-mafiosi recipients appear to have broken free from the strings attached to the gift. Impelled by overt religiosity cultivated in 'Ndrangheta, affiliates desire not a 'social distance' but a 'saintly distance' 'outside of society' ${ }^{\text {ii }}$ through the rare giving of free gifts, aspiring to Catholic ideals of altruism and sacrifice. This is indeed a paradoxical engagement, yet the free gift does create the potential to activate future relations. The free gift has a potential to become a vincolo; to chain, link or restrain, despite the fact recipients will never be obliged to make a return. In these rare cases the convention to return is broken.

\section{The Religious 'Ndrangheta}

Mafia is usually associated with violence, death, illegal trafficking and corruption, themes frequently explored in the anthropological literature (Blok 1974, Schneider and Schneider 1976, 1984, 2003, Chubb 1989, 1996, Zinn 2001). In this paper I am interested in a particular discourse about mafia that has thus far escaped academic attention. Contemplating how mafiosi in a western capitalist society such as Reggio Calabria enjoy a relatively tolerable public profile, I refer to the rare occasions that $21^{\text {st }}$ century mafia offer gifts which seem not to be politically and economically motivated. These gifts range from artefacts and monetary donations, to unreciprocated favours (favori senza reciproco), or the offering of disposal (disposizione). They fall under local categories such as 'unreciprocated favours' (favori senza reciproco), 'give without waiting for a return' (dare senza aspettarsi nulla in cambio), 'give without receiving' (dare senza ricevere), and 'donate without receiving anything in return' (donarsi senza aspettarsi nulla in cambio). In all these discourses emphasis on the unreturnability of the gift is strong.

Connections with local civil society and political infiltration could explain mafia economic and political viability, but does not justify why local non-affiliates are reluctant to condemn mafia or find it morally repugnant. Paul Sant Cassia (1993:773) notes that to form a sustainable argument regarding the "psychology and sociology of terror" we need to look beyond docility inflicted by terror and violence. This complex 
issue requires a careful examination of local moral systems, religious selfessentialisation, justice and retribution, and modes of relatedness. One such path to self-essentialisation is inspired by the religious ethos and altruism that 'Ndrangheta cultivates, partially materialised through free gifting. Altruistic gifts shape a divine profile for the mafiosi as they aspire to step outside of society. Free gifting acquires a historical and rhetorical potential which transcends time and has the possibility to engender relations. These gifts are narrativised, historisised, and finally mythologised.

Central to 'Ndrangheta religiosity is altruism and sacrifice. 'Ndrangheta in Reggio Calabria is perceived as a sovereign political entity, placing relatedness at the heart of its conceptualisation. 'Ndrangheta affiliates are linked through kinship ties, rituals of initiation, and elaborate myths of genesis. Rituals of initiation are multivalent webs of power and knowledge where numerous religious figures, symbols, and the substance of blood are employed to forge the new status of the 'Ndrangheta novice. The ritual is a re-enactment of an event believed to have occurred centuries ago between the human founder of 'Ndrangheta and its divine protector, Saint Michael the Archangel. Idiosyncratic knowledge that produces various forms of subjectification is believed to be transmitted during the initiation. Through volitional coercion the novice learns new forms of relating with the society of 'Ndrangheta, its religious protectors, and nonaffiliates. 'Ndrangheta draws heavily on Catholic religious imagery and the rhetorical projection of a society ${ }^{\text {iii }}$ oscillating between the 'sacred' and the 'profane' (cf. Schneider and Schneider 1984, Paoli 2003, Gratteri and Nicaso 2007, Nicaso 2007). A vow on Saint Michael the Archangel, sealed with blood, stresses the perpetual link between 'ndranghetisti and their religious protectors. A conceptualisation of relatedness between religious figures and humans allows for an imagining of a direct genealogical link to the saint-ancestor. Such allusions to a religious origin suggest a habitual self-essentialising of superiority that is cultivated among high-rank 'ndranghetisti.

The ranks of Santista (Holy One) and Vangelo (Gospel) are two of the most prestigious positions in the $21^{\text {st }}$ century 'Ndrangheta, characterised by an ambivalence regarding their 'criminal office' and the morality that the position entails. The ranks were specifically introduced into 'Ndrangheta hierarchy with the implementation of the Santa (Holy One) at the end of the 1960s (Paoli 2003, Oliva and Fierro 2007). The 
Santa was introduced as an exclusivist sect within the 'Ndrangheta with the aim to provide further links with economic and political sources within and outside Italy. Most researchers trace a change in the profile of the 'Ndrangheta to the period after the creation of the Santa and the elimination of the last 'old bosses' after the first 'Ndrangheta war (1974-76) (Paoli 2003:115). The Santa was an innovation not only because it radically changed the 'Ndrangheta's agro-pastoral ideology but also because it boosted mafiosi onto another level of 'doing politics' and global economic expansion. The 'classic' method of extortion - kidnapping - was abandoned and replaced with more 'modern' business methods. The construction of motorways from Salerno to Reggio Calabria and Jonio to Tirreno, the railway line from Naples to Reggio Calabria, as well as the city airport and industrial area of Lamezia Terme, have presented major opportunities for local mafiosi to enter the subcontracting game (Nicaso 2007:64).

The term Santa derives from mamma santissima (Most Holy Mother). Mamma santissima is a distinction of religion, referring to the Madonna and local 'Ndrangheta bosses as a mark of leadership and power. As a religious figure, the Madonna is deeply loved and respected by the 'ndranghetisti. Particularly adored is the Madonna di Polsi in Aspromonte, whose sanctuary is a locus of sentiment and knowledge production for the mafia families of Reggio Calabria.

Nevertheless, ethnographic substantiation of mafia enterprises, ranging from casual favour exchange to political infiltration, trafficking, extortion and murder, sketches anything but an altruistic profile for the mafiosi. In Reggio Calabria many argue that "they give you something in order to ask back double the favours. The modern 'ndranghetisti are corrupt, immoral, capitalists, and have lost the sense of honour. Only the old 'Ndrangheta is associated with giving and helping without asking for reciprocation. Today they only rarely offer their services for free (gratis). These people are really charismatic".

An obvious distinction between old and new 'Ndrangheta is highlighted here. Distinctions between the old and new 'Ndrangheta or between the agro-pastoral and the 'Ndrangheta of global expansion have been frequently explored by scholars as echoing pre-modern tropes of politicisation (cf. Chubb 1996, Schneider and Schneider 
2003). Informants associate the old 'Ndrangheta with virtues and values that are now lost in the name of money and corruption. The new 'Ndrangheta of the $21^{\text {st }}$ century is associated with political and economic control on a global-scale. Very few people have the charisma to give without asking for return, few have the virtue of being humble and thus have the potential to step outside of society.

\section{Offering Free Gifts: a story about a Car, a Book and a House}

\section{The Car}

Antonia, 50 years old, is university educated, highly politicised and frequents circles that could be classed as the 'high society' of Reggio Calabria. She is book-learned and a member of numerous local civic associations of philosophy, poetry and the arts. She owns a small car which has been stolen twice in the past. On both occasions Antonia approached the neighbourhood butcher, allegedly a high rank mafioso, complaining about the stolen car. The butcher reassured her that there was no need to worry. Antonia was comforted by this promise, and when she thanked him he humbly replied, "at your disposal" (a vostra disposizione). A few days later the car was outside Antonia's house. The butcher apologised that it had taken so long to recover the car as the gypsies (zingari) had stolen it.

Unfortunately her car was stolen for a third - and final - time. It could not be returned as "those who were controlling the neighbourhood were arrested in one of those ridiculous government attempts to show us they exist ${ }^{\text {,iv }}$. Antonia went to the carabinieri to report the larceny but "their computer did not work". After spending the day waiting for the 'computer to work' the carabiniere informed her that his shift was over and she would have to wait for his replacement. Antonia, very upset, replied, "Do not bother; I am going to the poliziotti". At the polizia she was told that the department for thefts was closed for the next two days.

Furious, Antonia cried, "I did well to go to the carabinieri first".

\footnotetext{
"And what did they tell you Signora?"
} 
Antonia acknowledges that this was an unreciprocated service, a free gift which comes under the categories 'unreciprocated favours' (favori senza reciproco) and 'donate without waiting for a return' (donarsi senza aspettarsi nulla in cambio).

\section{The House}

The following story concerns an old man and his old house. When his story is circulated it is framed as a mafia free gift. Nunzio, a man of 78, is a former professor of mathematics at a local secondary school. Having lost his wife at a young age he now lives alone as his two sons both work in North Italy, but visit him often. Nunzio has lived in the same small house for 40 years and his neighbours adore him as he is wise and always ready to offer advice.

As a young man Nunzio gave private lessons to students, one of whom was an up and coming 'ndranghetista of the neighbourhood. The student loved Nunzio and on many occasions offered his disposizione, which was however politely declined. Nunzio's humanistic disposition did not discriminate against clients affiliated with the 'Ndrangheta, but he meticulously abstained from further implications with "those who control" (quelli che controllano) the neighbourhood.

In 2006 Nunzio's landlady decided to sell the house, forcing him to relocate. The house was a real dump, but he liked it - it was where he had lived with his wife and raised his children. His sons attempted to persuade him that moving home was not difficult as they would arrange everything. Nunzio was not convinced and proposed to buy the house from the landlady, but the asking price of $€ 160,000$ was extortionate.

Before long the local 'Ndrangheta heard of the landlady's intentions. She was 'advised' that if she wanted to sell the house then it should only be to Nunzio. On one occasion the agent was intercepted outside the house whilst with a potential buyer and was explicitly told; "what the woman is doing is blatantly wrong, she should propose a more realistic price". 
Eventually Nunzio bought the house for $€ 95,000$ and is happy to die in the same place as his wife. Although never directly offered the house by the 'Ndrangheta, Nunzio acknowledged to his friends that this intervention was a desirable gift - the only welcome mafia gift in his life. When this story is circulated it is framed as a free gift. Such circulation creates the allusion of plentiful positive gifting, masking the rarity of mafia free gifts.

\section{The Book}

Antonia is a constitutive part of the local intelligentsia but her humility, charisma and philosophy of life makes her popular in many social circles. Concerning her relationship with the local 'Ndrangheta she says,

[[My father was never implicated in 'Ndrangheta affairs and neither were my brothers. Because we all come from the same area we show mutual respect and maintain the minimum of social relations with the famiglia that governs the quartiere. Apart from a salutation we have never had further relations. As a child I was schoolmates with the boss's daughter. We were not close friends but she was a nice girl and a good student. I remember one time I needed a book which I knew she owned. This book was very important because I had to prepare an essay on the history of Italy but my family did not have enough money to buy me the book. I thought that the girl could lend me the book and thus I went to her house to ask for it. Her father [the boss] happened to be at home at the time. When he understood that I wanted to borrow the book he gave it to me saying that from now on the book is mine and I no longer needed to return it to his daughter.]]

Antonia recalls that his "language was mild and kind; a very good person in general". Of utmost importance is the texture of memory that this act left in her mind.

That first 'Ndrangheta gift of her childhood remained unreciprocated as neither Antonia nor her parents have been approached by the mafiosi since. In a similar manner the more recent gifts of her adulthood are also unreciprocated. As Antonia states, "I know that they will never ask me for anything". Nunzio exhibits the same confidence that he will never need to reciprocate. He bases this conviction in the 
teacher-student relationship that he shared with 'one of them'. Respect that stems from friendship can be a motive for free gifts as "friendship may facilitate the management of underworld-connected crises because it allows the actors to avoid problematic reciprocation and obligation" (Pardo 1996:88).

On first inspection, ethnographic cases like those presented above resemble accounts of 'favour transactions' as widely documented by Mediterranean ethnographers ${ }^{\mathrm{vi}}$. Such transactions are based on either direct reciprocity - in the Maussian sense establishing a power balance between exchanging parties, or indirect reciprocity - in the Lévi-Staussian sense - presupposing the existence of trust and credit and thus generalised. The notion of the gift is central and stems from readings of The Gift (1954) or what Parry calls "the conventional exegesis" of Mauss's position (1986).

Anthropologists have paid close attention to the materialistic dimension of giving for engendering relations and the power asymmetries caught in the exchange. Parry notes that "the unreciprocated gift debases the recipient, and the charity of the "rich almoner' is condemned. Presumably it denies obligation and replaces the reciprocal interdependence on which society is founded with an asymmetrical dependence" (1986:458). Examining dan in India, Laidlaw argues that what is given is devalued both linguistically and in terms of treatment by both donor and recipient. What is given is not viewed as charity but as an "anonymous and undifferentiated substance ... which disappears once it has been given" (Parry 1986:622-623).

Only that the 'Ndrangheta free gift never disappears. The mafia desire to step outside of society is compromised by the inherent qualities of the free gift and the very way that relatedness is realised. The free gift has the potential to become a vincolo (a chain, link, restraint), a powerful notion of relatedness with binding potential.

\section{Humility and Charisma: Striving for Greatness}

In 'Ndrangheta religiosity humility and charisma are interrelated and complementary virtues. Humility is linked to an ethos of servanthood and sacrifice and fosters interrelatedness and companionship whilst charisma is associated with greatness and wisdom. Virtues and values have different contextual and historical valences. 
Aristotle and Homer's understanding of arete (virtue) differ from what is presented in the New Testament, which promotes virtues such as faith, hope and love, and views humility as one of the corner-stones in the formation of a Christian character (Aristotle and Homer consider it the moral for slaves). Despite differences, in both the New Testament and Aristotle's comprehension virtue empowers a person to attain the characteristic essential for exercising human telos (Louw 1999:176). Telos is the challenge to "enflesh" the 'Ndrangheta Gospel. The similarity between Scripture and 'Ndrangheta rhetoric in the treatment of gift and virtue is astonishing:

[[These gifts [virtues] are love, joy, peace, patience, friendliness, kindheartedness, faithfulness, humility and self-control. A person with these gifts is described in Scripture as wise and sensible (James 3:17 in Louw 1999:114).]]

Humility (umiltà) is a virtue and a gift that novice 'ndranghetisti vow during their ritual of initiation. Every 'Ndrangheta rank is a dote, that is a dowry and gift. 'Ndrangheta gifts its affiliates by receiving them into its society, a gifting that new affiliates need to distribute. Umiltà is a noble behaviour and a telos believed to be achieved by a minority of charismatic figures. This is a virtue reserved for higher rank affiliates who may possess humility and charisma.

Charisma, Max Weber argues, characterises "self-appointed leaders who are followed by those who are in distress and who need to follow the leader because they believe him to be extraordinarily qualified" (Gerth and Mills 1970:52). The 'routinisation of charisma' explains the legitimisation of mafia power. Raimondo Catanzaro (1988:37) argues,

[[At the beginning of his career the Mafioso must have been able to show certain extraordinary virtues, such as strength, ferocity, and astuteness: These were gifts that made it possible for him to build a following, create a cosca for himself, or to set himself at the head of another cosca. Once his charismatic virtues were recognised, he no longer needed to exercise violence directly; he could confine himself to threatening violence, and when he turned to it as a last resort, he usually did not use it directly, but through one or more members of the cosca.]] 
The mafioso finds out about a case where they can offer a free gift either directly from the potential recipient or indirectly from the potential recipient's social circle (see also Pardo 1996:86). The mafioso is always cautious when offering their disposizione, as in Antonia's cases, or avoids the offer completely as with Nunzio. During the act of offering elaborate speech registers ensure both parties that distance between them is maintained and the recipient is free to accept or decline the gift.

Mafiosi wrap their gifts in layers of social distancing. In her ethnography on Japanese gifting Joy Hendry (1993) argues that wrapping reflects politeness and social distance. She treats "layering and wrapping as synonymous, creating a metonymic relation that gives rise to the metaphor of wrapping as something that encompasses all that is layered, and has value added to it" (Trias i Valls 1999:34). Wrapping is as important as the gift itself because it does not conceal but rather adds further value to the gift. Trias i Valls (1999) takes the argument further, claiming that wrapping is not about reflecting but rather mystifying relations of power between givers and receivers. Asymmetrical dependence in cases of free gifts is downplayed by mafiosi with the use of elaborate speech levels employed to manipulate relative social status and avoid connotations of giving.

In central and southern Italy the rules of address, dare del Lei (to use the Lei) and dare del Voi (to use the Voi) are markers of politeness and respect (Tosi 2001:76-77). The over-use of the Voi (polite formal address) cultivates the mafioso profile associated with order, hierarchy and mystifying social distance. Even in one-to-one conversations among 'ndranghetisti the Voi is employed as a mark of etiquette and respect for hierarchy and a celebration of sharing the same society, the 'Ndrangheta. Culturally semantic terms such as Voi, Lei and disposizione are appropriated to encourage the ambivalence of the 'Ndrangheta free gift.

Disposizione is an ideological register implicit in dialogue between mafiosi gift givers and non-mafiosi recipients. It further debases the position of the gift giver so as asymmetry does not threaten the discourse of giving. Being at the disposizione of someone elevates the mafioso to a position of duty and sacrifice and objectifies the “ideal goals of social action towards a future existence" (Parry 1986:467). The idea of 
salvation, Gananath Obeyesekere argues, "is inherent in the historical world religions" with the prevalence of sin or religious morality to determine "hell for sinners and heaven for saints" (1968 in Parry 1986:467). In Parry’s words,

[[An elaborate ideology of the 'pure gift' is most likely to develop in state societies with an advanced division of labour and a significant commercial sector. But what is also in my view essential to its articulation is a specific type of belief system, as is suggested by the fact that in all of the major world religions great stress is laid on the merit of gifts and alms, ideally given in secrecy and without expectation of any worldly return (1986:467).]]

Thus far I have argued that categories of gifting falling under a general rubric of giving without receiving comply with inert mafioso religiosity and virtues towards a telos where charismatic figures are outside of society. Weber notes that "in order to do justice to their mission, the holders of charisma, the master as well as his disciples and his followers, must stand outside of the ties of this world, outside of routine occupations, as well as outside of the routine obligations of the family life". He recognises the dissolving possibilities of 'pure' charisma as "the force that disregards economy" (1970:248).

The desire to step outside of society is sustained by free altruistic gifts to selected individuals or by substantial church donations. Yet if the objective is to step outside of society is there potential for free gifts to create relatedness? Is this desire compromised? We must turn our attention to the multilayered potential inherent in discourses of relatedness.

\section{The Turn of the Screw: Vincoli and Gifts}

Jane and Peter Schneider rightly note that in receiving mafia gifts people feel vincolati, a term to denote a chain, link, bond and/or restraint. Recipients are "obliged for the foreseeable future, even if grudgingly" (2003:115). Vincolo, as a binding notion, appears in diverse social contexts, ranging from national politics to quotidian affairs between kin. 
Relatedness in Reggio Calabria is envisaged as spanning time and space, human and non-human entities (Pipyrou 2010). The yearning for relatedness is rich, providing evidence that the substantial-codings of kinship have undergone significant historical transformation (Franklin and McKinnon 2001:11). The substance-like abstract qualities of vincoli in Reggio Calabria articulate relational possibilities of power and hierarchy, violence and ambivalence and attempts to transcend society. Boundarybreaking is particularly celebrated among the 'Ndrangheta where affiliates are linked through a meticulous reworking of biological, social, and religious ties.

Vincoli can lay inactive and never realise the potential of relation, or can be highly restricting, superimposed and often abstract. Relationality, Marilyn Strathern argues, can emerge as not only analytic but as "an abstract value placed on relationships" (Strathern 2005:viii). The relations, connections and restraints of the vincolo are based on "a logic of power of articulation that acquires its own conceptual momentum" and as such have become a 'routine social fact' (Strathern 2005:7).

Precisely because vincolo has an abstract as well as a substantial value to realise relations I am more interested here in what vincolo does rather than what it is. On an everyday level people may feel obliged or even trapped by the vincoli that constrain them. On many occasions actors act against their will because they feel the vincoli of relatedness superimposed on them. In that sense participation in feuds, vendettas, political corruption and quotidian favours that burden people are explained as a result of the vincoli - a kind of virtual, superimposed mode of relatedness that has the inherent potential to be realised.

Gottfried Leibniz's doctrine of the 'vinculum substantiale' is pertinent here as an explicit theory of connections between monads. The 'vinculum substantiale' was employed as a concept that could possibly explain chaos and disorder, domination and subordination of connections between monads. Monads are the constituent parts of an aggregate and the 'vinculum substantiale' the connections/relations/restraints adhered to them. The 'vinculum' in itself was conceptualised by Leibniz as a thing-like substance that once superadded to the simple substances or monads could unite them. One of the signal features of the 'vinculum' is that whilst it changes nothing in the phenomena it creates a new being (Look 1999:80). The 'vinculum' can exist in or 
adhere to several distinct monads simultaneously, and yet can also exist apart from the monads (Look 1999:87).

When the vincolo and the monads are attached they become a unity of substance. There is always the potential for active unity, although not always realised. The vincolo is the most important constituent of the new aggregate as without the inherent properties in the relation the unity could not be formed. The monad could not combine with a substance that does not have the correct inherent properties. This answers the question of why specific vincoli get activated whilst other lie dormant. Thus we can say that the vincolo is at once a potential connection or relation and a unifying entity between actors, institutions and other monads in society. It is at once part of the structure, part of the aggregate, and a substance in its own right. When mafiosi give free gifts, regardless of their intention, they inherently create a vincolo.

In both cases presented above Antonia and Nunzio acknowledge that they feel vincolati, yet at the same time they are certain that this vincolo will be never realised into a relation. They are aware of this paradox and at the same they are aware that the very abstraction of the vincolo breaks the convention of the return.

\section{Conclusion}

Mafia in modern society is usually analysed in terms of violence and corruption. Despite its well documented global capitalist expansion, the maintenance of the 'Ndrangheta religious profile in a $21^{\text {st }}$ century context is complex. In mafia discourses free gifting is indeed rare, yet the persistent circulation of stories creates the allusion of plentiful positive gifting. This is one way 'Ndrangheta is adorned religiosity, altruism and sacrifice, maintaining a legitimised profile.

Antonia argues that she feels vincolata, despite the fact she is certain the vincolo will never be activated. This is the paradox the free gift creates, for both recipient and donor. The mafiosi try to step outside of society by altruistic free gifting but inherently cannot as they are bound by the same structure that allows them to envisage themselves as outside. The structure that encourages altruism and sacrifice 
through free gifting generates the potential for relatedness. Such ambivalence was not anticipated by Mauss.

On the one hand the potentiality for relatedness inherent in the aspired mafia $21^{\text {st }}$ century free gift does highlight the erosion that capitalism and commodities impose on gift exchange; an erosion obvious on gift exchange but not on the types of gifts. On the other hand this acts as a general reminder that we should not be hasty to assume that the gift in the $21^{\text {st }}$ century is always politically and economically motivated. It can be safely argued that the Maussian paradigm of the gift has definitely not lost its relevance in the $21^{\text {st }}$ century. Nevertheless, recently prolific literature suggests relations based on gift exchange are more and more 'mythical' (Venkatesan 2011), abstract thus rendering the actors vincolati, or 'nameless' as Monica Konrad (2005) has suggested in her account on anonymity, gift exchange and ova donors. In the rare cases of mafia free gifts "active not-knowing is implicated in the temporality of remembering the donor and the act of donation. There is rumination about what information could travel back to the donor" (Konrad 2005:170). By rendering such peculiarities intelligible, we challenge the view that the gift is something eternal, structural and unchanging. Often actors $d o$ aspire to dissolve the binding qualities of gifting and the free gift is an attempt to break away from social contracts and it is through free gifting that mafiosi attempt to step outside of modern society towards a telos of altruism and sacrifice.

\section{Acknowledgements}

I am grateful to Michael Carrithers, Victoria Goddard, Mark Jamieson, Daniel Knight, Bob Simpson, Marilyn Strathern, Àngels Trias i Valls and the editors Margaret Sleeboom-Faulkner and Anne-Meike Fechter for their valuable comments.

\footnotetext{
${ }^{\mathrm{i}}$ Under the generic rubric Italian Mafia are classed the four well-known criminal organisations that exist in Italy: Cosa Nostra in Sicily, 'Ndrangheta in Calabria, Camorra in Naples and Sacra Corona in Puglia. In discourse the term 'mafia' is often used interchangeably with any of the aforementioned mafias. It is believed that etymologically the word 'Ndrangheta derives from the Greek Andragathia, translated as 'act of courage, prudence, artfulness, glorious action, the mode that pertains to a man of glory' (Messina 1990:60).
} 
ii This is not to say that ontologically 'Ndrangheta is outside of society, but rather that 'ndranghetisti want to project the image of stepping outside of society towards their divine telos. Here the term society refers to the general society of Reggio Calabria. Nevertheless the term society is also associated with the 'Ndrangheta (see footnote iii).

iii Here I follow local commentary that often attributes the term società (society) or onorata società (honourable society) to 'Ndrangheta.

iv Antonia's critique goes beyond the 'absent state' argument. She explicitly criticises the DIA (Direzione Investigativa Antimafia - Antimafia Investigative Directorate), a new organisation with increased personnel to coordinate police divisions specialising in organised crime. The DIA reinforces the Parliamentary Antimafia Commission which was activated in 1963 with the scope of dealing with mafia throughout Italy. In her account Antonia refers to the events between August and September 2007 when the police arrested a number of 'ndranghetisti in Reggio Calabria.

${ }^{\mathrm{v}}$ The rivalry between carabinieri and poliziotti - two different police forces in Italy is renowned in Reggio Calabria. Many informants have expressed a deep dissatisfaction with the effectiveness of both institutions. When encountering a problem, people in Reggio Calabria utilise their connections with friends, relatives and wider political and economic networks rather than involve the police forces themselves. When I was in a difficult situation regarding an aggressive male neighbour I was advised not to go to the police but rather speak to friends in my social circle.

vi Significantly, Kenny (1960), Campbell (1964), Silverman (1965), Boissevain (1966), Gellner (1977), Loizos (1977), White (1980), Gilmore (1987), Moss (1995), and Pardo (1996), to name but a few.

\section{References}

Blok, A. 1974. The Mafia of a Sicilian Village, 1860-1960: A study of violent peasant entrepreneurs. Oxford: Basil Blackwell.

Boissevain, J. 1966. Patronage in Sicily‘. Man, 1 (1): 18-33.

Campbell, J. 1964. Honour, Family and Patronage: A study of institutions and moral values in a Greek mountain community. Oxford: Oxford University Press. 
Catanzaro, R. 1988. Men of Respect: A social history of the Sicilian Mafia. New York: The Free Press.

Chubb, J. 1989. The Mafia and Politics. Cornell Studies in International Affairs, Occasional Papers No. 23.

Chubb, J. 1996. The Mafia, the Market and the State in Italy and Russia. Journal of Modern Italian Studies, 1 (2):273-291.

Franklin, S. and S. McKinnon. (eds). 2001. Relative Values: Reconfiguring kinship studies. London: Duke University Press.

Gellner, E. 1977. Patrons and Clients. In Patrons and Clients in the Mediterranean, edited by E. Gellner and J. Waterbury. London: Duckworth.

Gerth, H. H. and C. Wright Mills. 1970. Introduction. In From Max Weber: Essays in sociology, by M. Weber. London: Routledge.

Gilmore, D. 1987. Aggression and Community: Paradoxes of Andalusian culture. New Haven: Yale University Press.

Gratteri, N. and A. Nicaso. 2007. Fratelli di Sangue: La 'Ndrangheta tra arretratezza e modernità: da mafia-agropastorale a holding del crimine. La storia, la struttura, $i$ codici, le ramificazioni. Cosenza: Pellegrini.

Hendry, J. 1993. Wrapping Culture: Politeness, presentation and power in Japan and other societies. Oxford: Oxford University Press.

Kenny, M. 1960. Patterns of Patronage in Spain. Anthropological Quarterly, 33:1423.

Konrad, M. 2005. Nameless Relations: Anonymity, Melanesia and reproductive gift exchange between British ova donors and recipients. Oxford: Berghahn Books.

Laidlaw, J. 2000. A Free Gift Makes No Friends. The Journal of the Royal Anthropological Institute, 6 (4): 617-634.

Loizos, P. 1977. Politics and Patronage in a Cypriot Village, 1920-1970. In Patrons and Clients in the Mediterranean, edited by E. Gellner and J. Waterbury. London: Duckworth.

Look, B. 1999. Leibniz and the 'Vinculum Substantiale'. Stuttgart: Steiner.

Louw, D. J. 1999. A Mature Faith: Spiritual direction and anthropology in a theology of pastoral care and counseling. Leuven: Peeters.

Mauss, M. 1954. The Gift: Forms and functions of exchange in archaic societies. London: Cohen and West. 
Messina, G. 1990. L'etimologia di "Màfia", "Camòrra" e "Ndràngheta". Acireale: Bonanno.

Moss, D. 1995. Patronage Revisited: The dynamics of information and reputation. Journal of Modern Italian Studies, 1(1): 58-93.

Nicaso, A. 2007. 'Ndrangheta: Le radici dell'orio. Roma: Aliberti.

Oliva, R. H. and E. Fierro. 2007. La Santa: Viaggio nella 'Ndrangheta Sconosciuta. Milano: RCS Libri.

Paoli, L. 2003. Mafia Brotherhoods: Organized crime, Italian style. Oxford: Oxford University Press.

Pardo, I. 1996. Managing Existence in Naples: Morality, action, and structure. Cambridge: Cambridge University Press.

Parry, J. 1986. The Gift, the Indian Gift and the "Indian Gift". Man, 21 (3): 453-473.

Pipyrou, S. 2010. Power, Governance and Representation: An anthropological analysis of kinship, the 'Ndrangheta and dance within the Greek linguistic minority of Reggio Calabria, South Italy. Unpublished doctoral thesis, Department of Anthropology, Durham University, United Kingdom.

Sant Cassia, P. 1993. Banditry, Myth, and Terror in Cyprus and Other Mediterranean Societies. Comparative Studies in Society and History, 35 (4): 773-795.

Schneider, J. and P. Schneider. 1976. Culture and Political Economy in Western Sicily. New York: Academic Press.

Schneider, J. and P. Schneider. 1984. Mafia Burlesque: the profane mass as a peacemaking ritual. In Religion, Power, and Protest in Local Communities, edited by E. Wolf, E. Berlin: Mouton.

Schneider, J. and P. Schneider. 2003. Reversible Destiny: Mafia, Antimafia, and the struggle for Palermo. Berkeley: University of California Press.

Silverman, S. 1965. Patronage and Community-Nation Relationships in Central Italy. Ethnology, 4 (2): 172-189.

Simpson, R. 2004. Impossible Gifts: Bodies, Buddhism and bioethics in contemporary Sri Lanka. The Journal of the Royal Anthropological Institute, 10 (4): 839-859.

Simpson, R. 2011. Managing Potential in Gamete and Embryo Donation: Reflections on transaction. Paper presentation to Anthropology Senior Seminar, Department of Anthropology, Durham University, United Kingdom, September 2011. 
Strathern, M. 2005. Kinship, Law and the Unexpected: Relatives are always a surprise. Cambridge: Cambridge University Press.

Sykes, K. 2005. Arguing with Anthropology: An introduction to critical theories of the gift. London: Routledge.

Tosi, A. 2001. Language and Society in a Changing Italy. Clevedon: Multilingual Matters.

Trias i Valls, M. A. 1999. Wrapped Gifts: Ritual prestations and social obligations in contemporary Japan. CSAC Monographs Online, 19. University of Kent, Canterbury: The Centre for Social Anthropology and Computing.

Venkatesan, S. 2011. The Social Life of a "Free" Gift. American Ethnologist, 38 (1): 47-57.

Weber, M. 1970. From Max Weber: Essays in sociology. London: Routledge.

White, C. 1980. Patrons and Partisans: A study of politics in two southern Italian comuni. Cambridge: Cambridge University Press.

Young, M. 1985. On Refusing Gifts: Aspects of ceremonial exchange in Kalauna. In Metaphors of Interpretation: Essays in honour of W. E. H. Stanner, edited by Diane Barwick, and Marie Reay. Canberra: Australian National University.

Zinn, D. 2001. La Raccomandazione. Clientelismo vecchio e nuovo. Rome: Donzelli. 